\title{
The Development of Patients' Role Model in Improving Patient Safety Inpatient Room
}

\author{
Julintha Theresia br Sebayang ${ }^{1}$, Setiawan ${ }^{2}$, Bustami Syam ${ }^{3}$ \\ ${ }^{1}$ Correspondence Author: julintha2020@gmail.com \\ ${ }^{1}$ Master's in Nursing Administration, Faculty of Nursing, Universitas Sumatera Utara, Medan, Indonesia \\ 2Faculty of Nursing, Universitas Sumatera Utara, Medan, Indonesia \\ ${ }^{3}$ Faculty of Engineering, Universitas Sumatera Utara, Medan, Indonesia
}

I N D E X I N G

Keywords:

Patients' role model;

Inpatient room;

Patient safety;

Kata kunci:

Model peran pasien;

Ruang rawat inap;

Keselamatan pasien;

\begin{abstract}
A B S T R AC T
Patients have a significant role in improving their own safety. Their active involvement in planning, providing health services, monitoring, and evaluating treatment can improve health services. This study aims to develop a model of patients' role in improving patient safety in the inpatient room at Universitas Sumatera Utara Hospital. It is a qualitative research with action research design. Participants in this study were 15 nurses from 5 inpatient rooms. Data were collected using an online Focus Group Discussion (FGD), using observation form, field notes, and quantitative assessments using a questionnaire. Data were analyzed using content analysis and simple statistics. This study produced 4 models of the patients' role that can be used in inpatient rooms and increase the nurses' knowledge about the patients' role in improving patient safety. This study concludes that the model of patients' role can be used as a reference in increasing the patients' role and reducing the occurrence of adverse events when the patients are hospitalized so that patient safety can be achieved.
\end{abstract}

Pasien memiliki peran yang signifikan untuk ikut ambil bagian dalam meningkatkan keselamatan pasien sendiri. Keterlibatan aktif pasien dalam perencanaan, pemberian pelayanan kesehatan, monitoring dan evaluasi perawatan dapat meningkatkan pelayanan kesehatan. Penelitian ini bertujuan untuk mengembangkan model peran pasien dalam meningkatkan keselamatan pasien di ruang rawat inap rumah sakit Universitas Sumatera Utara. Penelitian ini merupakan penelitian kualitatif dengan desain action research. Partisipan dalam penelitian ini adalah perawat pelaksana berjumlah 15 orang dari 5 ruangan rawat inap. Data dikumpulkan menggunakan focus group discussion (FGD) secara online, menggunakan lembar observasi, field note, dan penilaian kuantitatif menggunakan kuesioner. Data dianalisis menggunakan konten analisis dan statistik sederhana. Penelitian ini menghasilkan 4 model peran pasien yang dapat digunakan di ruang rawat inap dan peningkatan pengetahuan perawat tentang peran pasien dalam meningkatkan keselamatan pasien. Kesimpulan dari penelitian ini menunjukkan bahwa model peran pasien dapat digunakan sebagai acuan dalam meningkatkan peran pasien dan mengurangi terjadinya kejadian buruk saat pasien dirawat di rumah sakit sehingga keselamatan pasien dapat tercapai.

C 2020 JMMR. All rights reserved

Article history: Received 2020-11-13; Revised 2020-11-25; Accepted 2020-12-29

\section{INTRODUCTION}

In providing quality essential health services, patient safety is a goal to be achieved to prevent mistakes that endanger patients (WHO, 2019). Several data confirm that nearly 134 million adverse events and 2,620,412 deaths are estimated to occur annually due to unsafe medical care in low-middle income countries such as 3.2\% adverse drug events and $5.1 \%$ falls experienced by patients during hospitalization (National Academies of Sciences, Engineering, and Medicine, 2018). In high-income countries, 1 in 10 patients are injured while receiving treatment in hospital (Slawomirski et.al., 2017). Medication errors are a major cause of injury and cost an estimated US \$ 42 billion per year (Aitken et al., 2012). This is due to the failure 
to carry out standard operating procedures for storing LASA drugs properly, ineffective communication between health care providers, lack of verification prior to drug administration, and lack of involvement of patients in their own care (WHO, 2019).

A research conducted by Rainey et al., (2015) on 13 patients and 7 families in hospital in the UK through in-depth interviews found that patients who were hospitalized, in giving their opinion, were influenced by their ability to be aware of changes in clinical conditions, their ability to monitor themselves, comfort and trust in health workers, culture, and health care system they receive. A study was conducted on nurses in Malaysia with $60.9 \%$ of nurses working in teaching hospitals, $39.1 \%$ of nurses working in non-teaching hospitals, $72.0 \%$ of nurses working in unaccredited hospitals, and $28.0 \%$ of nurses working in accredited hospitals. The results indicated that nurses who work longer hours have a significant relationship with patient safety through patient-centered care, in which patients who are more involved and participate in care guidelines and procedures are less likely to experience harm. Results also demonstrated that nurses with perceptions of patient-centered care are more willing to interact with patients longer and give more time to provide efficient care (Jarrar et al., 2019).

Furthermore, results of a study by Bishop \& Macdonald, (2017) 4 conducted in Canada on 10 patients and 27 nursing staff on patient involvement in patient safety resulted in 4 themes: the patients want to be controlled by the nurse by asking what the patient is asking, the patients feel connected to the services provided and involved in it through sharing information with nurses, patients want nurses to jointly face obstacles related to their health conditions, and share responsibility for patient safety. Accordingly, patients need to have a role in improving the quality and safety of the treatment they receive individually. Patients participation is seen in their active involvement in planning, providing health services, monitoring and evaluating their own care in order to prevent incidents, reducing negative impact of medical errors in order to achieve patient safety (Hurwitz, 2011; Schwappach et al., 2010; Skagerström et al., 2017).

In Indonesia, it is mandatory to apply 6 Patient Safety Standards in hospitals and the assessment is carried out using the Hospital Accreditation Instrument. Moreover, patient safety during treatment can be improved by the involvement of patients who are actually partners in the service process (KARS, 2019., Kemenkes, R. I, 2015). A model of patients' role in the inpatient room is usually made in the form of writing attached to the wall of the patient's room near the door of the patient's room with the title "Langkah-langkah keselamatan untuk mencegah pasien jatuh" [Safety measures to prevent patients fall] and "Langkah-langkah mencuci tangan dengan menggunakan handrub dan handwash" [How to hand rub? - How to hand wash?]. It does not include the six patient safety goals, so it is necessary to create a model in improving patient safety in the inpatient room. Therefore, this study aims to develop a model of patients' role in improving patient safety in the inpatient room of a government hospital in Medan.

\section{RESEARCH METHOD}

This research is a qualitative research design with action research consisting of 4 stages including reconnaissance, planning, acting and observing, and reflecting (Kemmis et al., 2014). Participants in this study were 15 nurses from 5 inpatient rooms at a government hospital in Medan. Participants were selected using purposive sampling based on the following inclusion criteria: 2 years of work experience, graduated with a Ners (nurse 
professional education), and had attended training related to patient safety goals. Data were collected from June to August 2020.

The first stage in action research was reconnaissance, which was a preliminary study stage in which study location identification and prolonged engagement with partisipants were conducted, the nurses' knowledge of the patients' role model in improving patient safety is measured and themes. Data collection was carried out using an online focus group discussion (FGD) using the Zoom Meeting application due to the Covid-19 pandemic situation, selfreports and field notes. Data collection tools included: voice recorder, FGD guideline, questionnaire about nurses' knowledge about the patients' role in improving patient safety.

The second stage was planning in which the researchers confirmed back to the participants regarding the results of the FGD in trancripts form, and also complete explanation of the data obtained with the research result and literature review, formulated a plan to solve the problems found in the reconnaissance stage which aimed to make improvements. At this stage, the development of a tentative model of patients' role in improving patient safety was also undertaken. The third stage included acting and observing in which the researchers carried out all the plans related to the tentative of patients' role model. Observation of the implementation of the patients' role model in improving patient safety by nurses was also carried out at this stage. Data collection tool using observation sheets for the implementation of patient's role in improving patient safety by nurses.

The fourth stage was reflecting, which aimed at gathering information related to nurses' experiences regarding the implementation of tentative model of patients' role in improving patient safety in the inpatient room. Data collection was carried out using an online focus group discussion (FGD) using the Zoom Meeting, self-reports and field notes. Data collection tools included: voice recorder, FGD guideline, questionnaire about nurses' knowledge about the patients' role in improving patient safety. More importantly, at this stage, there was a remeasurement of the nurses' knowledge after the implementation of the patients' role model in improving patient safety in the inpatient room and themes.

Moreover, qualitative data were analyzed using content analysis method. Steps in conducting data analysis are: compile and read all transcripts, identify and write significant statements into prepared tables to facilitate categorization, provide codes for each statements, the similar statements and the code group into categories, re-identify the suitability of placement in each category, group similar categories determine themes and sub-themes. Furthermore, reconnaissance stage, which was a preliminary study, and cycle of action research spiral consist of plan, act and observe, and reflect as shown in the following figure.1:

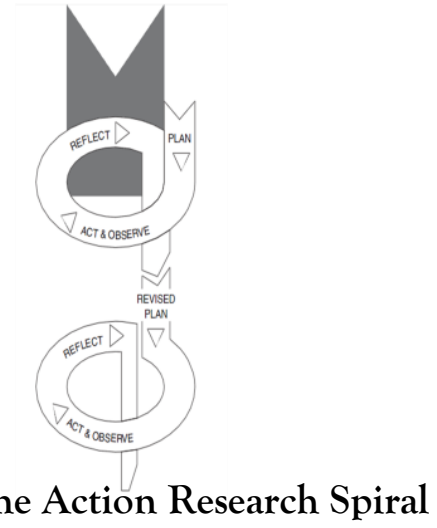

Figure. 1 The Action Research Spiral

Resource: Kemmis, S., McTaggart, R., Eु Nixon, R. (2014). The Action Research Planner:Doing Critical Participatory Action Research. Singapore: Springer Science Business Media Singapore 
Importantly, quantitative data analysis obtained from observational knowledge was presented using descriptive statistical test. This was done to identify the differences in the average knowledge value of the nurses' knowledge about the patients' role in improving patient safety before and after implementation. This study has received ethical approval from the Research Ethics Committee, Universitas Sumatera Utara (No: 77/KEP/USU/2020).

\section{RESULT AND DISCUSSION}

The characteristics of the participants who carried out the implementation of the patients' role model in improving patient safety inpatient room are described in table 1.

This study consisted of 4 stages including reconnaissance, planning, acting and observing, and reflecting. In the reconnaissance stage, researchers conducted a preliminary study, assessed participants' knowledge, observed the implementation of the patients' role in improving patient safety in the inpatient room, and observed documentation of the implementation of the patients' role. The reconnaissance stage was carried out by researchers for two weeks starting from 23 June 2020 to 7 July 2020. Themes in this stage include: the implementation of patient safety that involves patient's role, monitoring the involvement of patient's role, the obstacles faced in the implementation of patient safety involving patient' role, supporting factors in the implementation of patient safety involving patient' role, expectation to enhance patient's role in the implementation of patient safety. At this stage, the problem found in general was that there was no model of patients' role in improving patient safety in the inpatient room. It was, therefore, important to develop a model of patient's role in order to improve patient safety in the inpatient room.

Table. 1 The demographic characteristics of partisipants $(n=15)$

\begin{tabular}{|c|c|c|}
\hline Variables & Frequency & Persentage \\
\hline \multicolumn{3}{|l|}{ Age } \\
\hline $25-30$ years & 13 & 86,7 \\
\hline $31-35$ years & 2 & 13,3 \\
\hline \multicolumn{3}{|l|}{ Gender } \\
\hline Male & 2 & 13,3 \\
\hline Female & 13 & 86,7 \\
\hline \multicolumn{3}{|l|}{ Length of Work } \\
\hline $1 \mathrm{~s} / \mathrm{d}<3$ years & 4 & 26,7 \\
\hline $3 \mathrm{~s} / \mathrm{d}<5$ years & 11 & 73,3 \\
\hline \multicolumn{3}{|l|}{ Position } \\
\hline Team Leader & 3 & 20,0 \\
\hline Associate Nurse & 12 & 80,0 \\
\hline \multicolumn{3}{|l|}{ Education Level } \\
\hline Bachelor of Nursing & 0 & 0 \\
\hline Ners & 15 & 100,0 \\
\hline \multicolumn{3}{|l|}{ Patient Safety Training } \\
\hline Yes & 15 & 100,0 \\
\hline No & 0 & 0 \\
\hline
\end{tabular}

Resource: Data Analyzed (2020)

It is known that the majority of the participants were $25-30$ years old (13 people/86.7\%), most of them were females (13 people/86.7\%). Based on the length of service, the average participant had worked for 3 to $<5$ years at a government hospital in 
Medan (11 people/73.3\%), the majority of which had duties as executor nurse (12 people/80.0\%). In addition, all nurses had completed Ners program (15 people/100\%), and all had attended patient safety training (15 people/100\%).

Table. 2 The nurses' knowledge of the patients' role model in improving patient safety before implementation

\begin{tabular}{|c|c|c|c|}
\hline Knowledge & Absolutely frequency (n) & Relative & frequency $(\%)$ \\
\hline Good & 11 & & 73,3 \\
\hline Enough & 4 & & 26,7 \\
\hline Less & 0 & & 0 \\
\hline Mean & & & \\
\hline
\end{tabular}

Resource: result from the questionnaire of the nurses' knowledge about a model of patients' role in improving patient safety at the reconnaissance stage

Table. 2 shows the nurses' knowledge about developing model of patient's role in improving patient safety. It demonstrates that 11 people $(73.3 \%)$ have good knowledge about the patients' role in improving patient safety, while 4 people $(26.7 \%)$ have moderate knowledge with a mean score of 22.5.

At the planning stage, the researchers formulated plans in developing tentative model of patient's role in improving patient safety in the inpatient room on 8 July 2020 by involving 15 nurses from 5 inpatient rooms through the implementation of online FGD using the Zoom Meeting application. The implementation of the patients' role model in improving patient safety with nurses was carried out for 2 months. Besides, expert test for model of patient's role was conducted by three nurses who were experts on patient safety goals.

At the stage of acting and observing, the first activity was an online FGD using the Zoom Meeting application to compile a tentative model of patients' role which was held on 9 July 2020. This activity involved 15 nurses from 5 inpatient rooms. The next FGD was the formation of a team to carry out a model of patient's role which was held on 10 July 2020, while the implementation of the model of patients' role in improving patient safety with 15 nurses was held on 13 July 2020 - 5 August 2020. Implementation was carried out in 4 inpatient rooms and 1 maternity room. Observations were made in two rooms in one day except for the observation of the maternity room using the observation sheet. The implementation started at 09.00 a.m. - 11.00 a.m. and 03.00 p.m. - 17.00 p.m. which were adjusted to the shift of the nurses in each room. Observations were conducted during education on patient safety targets for new patients, schedule for administering drugs to patients, education on preparation for surgery to patients, and patients planning to go home for outpatient treatment adjusted to the Covid-19 pandemic conditions. In the first week of the implementation of the patients' role model, there were still found that the identity bracelet and risk of falling triangle were detached and the patient did not inform the nurse, and the bed support was not installed for patients with low or high risk of falling. However, along with implementation, the model of patients' role could run optimally.

The last one, at the reflecting stage, researchers conducted an FGD on 6 August 2020 with 15 participants from 5 inpatient rooms to explore information related to nurses' experiences regarding the implementation of the patient's role model in improving patient safety in the inpatient room and participants' knowledge after participating in the 
implementation of model of the patient' role in improving patient safety in inpatient rooms. This stage covered: experiences of implementing a model of patients' role in patient safety, constraints when implementing it, findings when implementing patients' role model, factors driving the enhancement of the patients' role, and suggestions and expectations in improving the patients' role.

\section{Output of action research}

The output of action research is a model of the patient' role in improving patient safety in the inpatient room. This model refers to six patient safety goals which include identifying patients correctly; improving effective communication; increasing the safety of high-alert medications; the implementation of a precise location, precise procedure, precise patient surgery undergoing the procedures; reducing the risk of infection related to health services, and reducing the risk of injury from falling patients (Joint Commission International, 2017).

There are 4 models for the patient' role consisting of 17 items. Below are the models:

Information resources, consisting of: mentioning 2 out of 4 identities, namely the patient's name, date of birth, medical record, and National Identity Number; providing information to nurses regarding health conditions; confirming the marking of surgery site to prevent wrong-site surgery; undergoing verification procedures before going to the operating room to ensure that all documents related to patients, photos (imagery), and also relevant examination results are in accordance with surgical procedure. Partnership, consisting of: understanding education given by nurses, building effective communication with nurses, not removing the marking of the surgery site, and reminding nurses to wash their hands.

Self-monitoring, consisting of: reminding nurses if the identity bracelet is detached, notifying nurses if the yellow sticker and risk of falling triangle has not been installed, reporting side effects of medication, alerting nurses if an infection occurs, and reporting complaints to nurses. Self-motivation, consisting of: washing hands in 6 steps using soap or hand rub; installing bed supports to prevent falls; fasting before diagnostic tests; wearing an identity bracelet; perform pre-surgery procedures, namely 6-8 hours fasting, shower 3 hours before surgery, shaving, cutting nails; removing jewelry and dentures; and not wearing nail polish and make up. The schemes of the patients' role model in improving patient safety in the inpatient room include:

\begin{tabular}{|c|c|c|c|}
\hline \multicolumn{4}{|c|}{ THE ROLE OF THE PATIENT } \\
\hline 38 & 38 & 38 & 38 \\
\hline INFORMATION RESOURCES & PARTNERSHIP & SELF MONITORING & SELF MOTIVATION \\
\hline $\begin{array}{l}\text { 1. Mentioning } 2 \text { out of } 4 \\
\text { identities } \\
\text { 2. Providing information to } \\
\text { nurses } \\
\text { 3. Confirming the marking of } \\
\text { surgery site } \\
\text { 4. Undergoing verification } \\
\text { procedures before going to } \\
\text { the operating room }\end{array}$ & $\begin{array}{l}\text { 1. Consisting of: } \\
\text { understanding education } \\
\text { given by nurses } \\
\text { 2. Building effective } \\
\text { communication with } \\
\text { nurses } \\
\text { 3. Not removing the marking } \\
\text { of the surgery site } \\
\text { 4. Reminding nurses to wash } \\
\text { their hands }\end{array}$ & $\begin{array}{l}\text { 1. Reminding nurses if the } \\
\text { identity bracelet is } \\
\text { detached } \\
\text { 2. Notifying nurses if the } \\
\text { yellow sticker and risk of } \\
\text { falling triangle has not } \\
\text { been installed } \\
\text { 3. Reporting side effects of } \\
\text { medication } \\
\text { 4. Alerting nurses if an } \\
\text { infection occurs } \\
\text { 5. Reporting complaints to } \\
\text { nurses }\end{array}$ & $\begin{array}{l}\text { 1. Washing hands in } 6 \text { steps } \\
\text { using soap or hand rub } \\
\text { 2. Installing bed supports to } \\
\text { prevent falls } \\
\text { 3. Fasting before diagnostic } \\
\text { tests } \\
\text { 4. Wearing an identity } \\
\text { bracelet } \\
\text { 5. Perform pre-surgery } \\
\text { procedures }\end{array}$ \\
\hline
\end{tabular}

Schemes. 1 Model of the patient' role in improving patient safety in the inpatient room at a Government Hospital in Medan

Resource: result from FGD research 


\section{Outcomes of action research}

The outcome of this study is an increase in the nurses' knowledge about the model of patients' role in improving patient safety in the inpatient room at a government hospital in Medan. A study conducted by Hurwitz (2011) found that patients must have a role in improving the quality and safety of the treatment or care they receive. Patients taking part in managing their health such as administering drugs or using medical equipment affect their safety, especially if it is not done properly.

Table 3. The nurses' knowledge of the patients' role model in improving patient safety after implementation

\begin{tabular}{|c|c|c|c|}
\hline Knowledge & Absolutely frequency (n) & Relative & frequency $(\%)$ \\
\hline Good & 13 & & 86,7 \\
\hline Enough & 2 & & 13,3 \\
\hline Less & 0 & & 0 \\
\hline Mean & & & \\
\hline
\end{tabular}

Resource: result from the questionnaire of the nurses' knowledge about a model of patients' role in improving patient safety at the reflection stage

Table. 3 indicates the increase in the mean score of the nurses' knowledge about the model of patients' role in improving patient safety after implementation was 28.0. The problem found at the reconnaissance stage that had been implemented was the absence of a model of patients' role in improving patient safety in the inpatient room. The results of a study conducted by Schwappach et al., (2010) confirmed that the absence of a patient's role can lead to errors, one of which is in drug administration so that providing a model of patients' role in improving patient safety can help prevent any kind of adverse events.

The identification of problems in this study could be found due to the trustworthiness between the researchers and the participants. Prolonged engagement is a technique used by researchers to maintain participant trust. Prior to the commencement of this study, the researchers had made an approach in about 1 year with participants since the researchers were undergoing practicum in the Strategic Planning and Advanced Administration course in Nursing. It is important to build trust and good relations with participants in data collection activities in order to obtain an in-depth understanding of the culture, language, or views of the group being studied and to test for misinformation (Tappen, 2016).

One of the ways to collect data in action research is through Focus Group Discussion (FGD). FGD is used to collect qualitative data in a study on a group of people usually consisting of 5-10 participants or more who are planned to gather to discuss certain topics that have characteristics that are suitable for the study, known as group interviews (Beck, 2013).

The increase in the nurses' knowledge related to the patient's role model has a positive impact on the implementation of patient safety. According to Amiri et al., (2018), individuals who receive similar information continuously will have good knowledge and can improve their skills. So that when the nurse implements the patient's role model, patient can also understand their role in improving patient safety.

The planning stage is the preparation of planning activities carried out in action research. At this stage, there was a discussion of planning related to the date and place of implementation, socialization with participants regarding the implementation of activities, the form to be used and what changes to achieve. Planning aims to make improvements. At 
this stage, the orientation was aimed at researchers on how to collaborate with research participants. Existing planning is a plan to make changes through language, practices and activities, how the relationship occurs between people and organizations, and how to structure the desired results (Kemmis et al., 2014).

At the stage of acting and observing, the researchers conducted all the planning by involving 15 nurses, based on the results of the FGD at the reconnaissance stage, a questionnaire on the nurses' knowledge about the model of patients' role, and a literature review as a support for the implementation that was to be implemented. This is in line with the explanation given by Paré et al., (2015) stating that literature review is an important part of a study considering that increasing knowledge in a study must be based on research that has previously been carried out. By making relevant literature review, we can understand the breadth and depth of the study to be carried out and see the problems. At the acting stage, the researchers made initial preparations that aimed to identify problems by finding a literature review that suited the needs of developing a model of patients' role that the researchers and participants wanted to achieve to improve patient safety in the inpatient room and also to compile a tentative model of patients' role.

However, there was a schedule change in the development of a model of patients' role to improve patient safety in the inpatient room due to the ongoing pandemic situation, which necessitated physical distancing with participants so that focus group discussion (FGD) activities were carried out online using the Zoom Meeting application. Kemmis et al., (2014) strongly advocated that the stage of acting and observing is the stage for implementing the plan that has been prepared and observing the work that is being done.

During this study, the competence of nurses associated with patient-centered care, especially the part that respects patient perspectives and the environment that supports patient safety, is a success factor for nurses that greatly affects the patients' role in the health care they live (Hwang et al., 2019; Jarrar et al., 2019). In addition, positive behavior and attitudes of nurses and other health workers such as responding to information provided by patients, building good cooperation, understanding their needs show that nurses understand the conditions and needs of patients during treatment (Flink et al., 2012; Ringdal et al., 2017). Nurse during acting and observing in this stage, must increase patient participation by motivating, providing relevant information and having the competence to support, lead and provide the needed resources.

Increased patient participation gives patients confidence that they have the ability to prevent medical errors so that their role is very important to prevent unexpected events (Tobiano et al., 2015), for example reminding health workers to wash their hands or telling them if they are not wearing an ID bracelet (Davis et al., 2012). In the first week of the implementation of the patients' role model, observation showed for example risk of falling triangle were detached and the patient did not inform the nurse, but the increased role of the patient can be showed from observation also during the research where implementation could run optimally. Patient contribution in providing input is substantial to strengthen patient safety service practices in the health team (Schwappach, 2010). The nurses' knowledge has also increased along with the implementation of the model of the patient's role which can be seen while providing education to patients, so it becomes a very important activity in improving patient safety. It is in line with a study conducted by Davis et al., (2012) which affirmed that educating and motivating patients to report directly on matters regarding errors in providing health services must be planned in advance to increase their participation 
(Davis et al., 2012), and increase satisfaction, independence in running the health programs they receive (Auld, 2017). Education can also improve the quality of health services provided (Wu et.al.,2017).

Reflecting is the final stage of the action research cycle to evaluate the implementation of the patient's role model in improving patient safety. Besides, at this stage, the nurses' knowledge was also evaluated using self-reports. After implementation, the mean score from self-reports of the nurses' knowledge about the model of patients' role in improving patient safety has increased. According to Polit \& Beck (2018), the final result of action research is not only related to knowledge but also to empowerment and awareness raising. This stage is carried out in several ways including analyzing, synthesizing, interpreting, explaining and drawing conclusions as well as expanding the output studies that have been compiled (Kemmis et al., 2014).

During the process of the implementation of the patient's role model, it is important to see how the nurse and patient collaborate which can be seen when the patient's role model is implemented. Observations were conducted during education on patient safety targets for new patients, schedule for administering drugs to patients, education on preparation for surgery to patients, and patients planning to go home for outpatient treatment. Referring to a research by Ding et al., (2019), patient participation increases satisfaction not only for patients but also for nurses. Collaborating with patients makes nurses more able to enjoy the work they do, because patient safety in providing services can be improved by the involvement of patients who are partners in the service process (Kemenkes, R. I, 2015). Importantly, the process of the implementation of the patients' role model could be carried out well because of the communication between the nurses and the patients. Nurses can advise the patients with effective communication and an open attitude so that the patients can read and understand generally drug labels and report anything that is not in accordance with the procedures previously described (Schwappach, 2010). Good communication between nurses and patients is a means for nurses to get feedback from patients regarding the services provided (Ding, 2019). Effective communication can also prevent sentinel and adverse events (Burgener, 2020). A trusting relationship can also be established between nurses and patients due to the interactions therein (Pomey et al., 2015).

An increase in the nurses' knowledge of the model of patients' role was also assessed before and after implementation of the model in which the mean score before implementation was 22.5 and after implementation was 28.0. According to Amiri et al., (2018), knowledge about patient safety can have a good impact on patient safety culture, and also the skills of nurses as educators in carrying out patient safety programs (Jang \& Lee, 2017).

\section{CONCLUSION}

This study is an action research that produces 4 models for the patients' role in improving patient safety in inpatient rooms. This model of the patient's role can be used as a reference in increasing the patient's role and reducing the occurrence of adverse events when the patients are hospitalized so that patient safety can be achieved. There are several limitations during the study. The first one is the Covid-19 pandemic condition that occurred requiring physical distancing between researchers and participants and limited interaction with patients being treated in the inpatient room so that Focus Group Discussion (FGD) with patients cannot be carried out. 
The researchers made several alternatives as an attempt to overcome the limitations of this study including Focus Group Discussion (FGD) and the preparation of tentative models for the patients' role which were carried out online using the Zoom Meeting application. In addition, observations were conducted during education on patient safety targets for new patients, schedule for administering drugs to patients, education on preparation for surgery to patients, and patients planning to go home for outpatient treatment. The second one is that the implementation of the patients' role model was only carried out for one month (implementation in planning should be conducted two months) due to the Covid-19 pandemic.

Finally, the researchers recommend that this model of patients' role can be used as a basis for developing nursing science in providing nursing care, and can be used by nurses as a reference in providing education to patients regarding patient safety goals.

\section{REFERENCES}

Aitken, M., \& Gorokhovich, L. (2012). Advancing the Responsible Use of Medicines: Applying Levers for Change. SSRN Electronic Journal. doi:10.2139/ssrn.2222541

Amiri, M., Khademian, Z., \& Nikandish, R. (2018). The effect of nurse empowerment educational program on patient safety culture: A randomized controlled trial. BMC Medical Education, 18(1), 1-8. https://doi.org/10.1186/s12909-018-1255-6

Auld, M. E. (2017). Health Education Careers in a Post-Health Reform Era. Health Promotion Practice, 18(5), 629-635. https://doi.org/10.1177/1524839917726495

Beck, C. T. (2013). Routledge international handbook of qualitative nursing research. Routledge

Bishop, A. C., \& Macdonald, M. (2017). Patient involvement in patient safety: A qualitative study of nursing staff and patient perceptions. Journal of Patient Safety, 13(2), 82-87. https://doi.org/10.1097/PTS.0000000000000123

Burgener, A. M. (2020). Enhancing communication to improve patient safety and to increase patient satisfaction. Health Care Manager, 39(3), 128-132. https://doi.org/10.1097/HCM.0000000000000298

Davis, R. E., Sevdalis, N., \& Vincent, C. A. (2012). Patient Involvement in Patient Safety: The Health-Care Professional's Perspective Background: Despite increasing recognition that patients could play an. 8(4), 182-188. http://group.bmj.com/

Ding, B., Liu, W., Tsai, S. B., Gu, D., Bian, F., \& Shao, X. (2019). Effect of patient participation on nurse and patient outcomes in inpatient healthcare. International Journal of Environmental Research and Public Health, 16(8). https://doi.org/10.3390/ijerph16081344

Flink, M., Öhlén, G., Hansagi, H., Barach, P., \& Olsson, M. (2012). Beliefs and experiences can influence patient participation in handover between primary and secondary care - A qualitative study of patient perspectives. BMJ Quality and Safety, 21(SUPPL. 1). https://doi.org/10.1136/bmjqs-2012-001179

Hurwitz, B., \& Sheikh, A. (Eds.). (2011). Health care errors and patient safety. John Wiley \& Sons.

Hwang, J. I., Kim, S. W., \& Chin, H. J. (2019). Patient Participation in Patient Safety and Its Relationships with Nurses' Patient-Centered Care Competency, Teamwork, and Safety Climate. Asian Nursing Research, 13(2), 130-136. https://doi.org/10.1016/j.anr.2019.03.001 
Jang, H., \& Lee, N. J. (2017). Patient safety competency and educational needs of nursing educators in South Korea. PLoS ONE, 12(9), 1-18. https://doi.org/10.1371/journal.pone.0183536

Jarrar, M., Minai, M. S., Al-Bsheish, M., Meri, A., \& Jaber, M. (2019). Hospital nurse shift length, patient-centered care, and the perceived quality and patient safety. International Journal of Health Planning and Management, 34(1), e387-e396. https://doi.org/10.1002/hpm.2656

Joint Commission International. (2017). Standar Akreditasi Rumah Sakit Termasuk Standar Untuk Rumah Sakit Pendidikan. $6^{\text {th }}$ ed.

KARS (2019). Standar Nasional Akreditasi Rumah Sakit Edisi 1.1. Jakarta: KARS

Kemenkes, R. I. (2015). Pedoman nasional keselamatan pasien rumah sakit (patient safety). Edisi III.

Kemmis, S., Mc,Taggart, R., \& Nixon, R. (2014). The action Research Planner Doing critical Participatory Action Research.Singapore : Springer Science+Bussines Media Singapore.

National Academies of Sciences, Engineering, and Medicine (2018). Crossing the global quality chasm: Improving health care worldwide. Washington, DC: The National Academies Press. doi: 10.17226/25152.

Paré, G., Trudel, M. C., Jaana, M., \& Kitsiou, S. (2015). Synthesizing information systems knowledge: A typology of literature reviews. Information and Management, 52(2), 183199. https://doi.org/10.1016/j.im.2014.08.008

Polit, D. F., \& Beck, C. T. (2018). Essentials of nursing research: Appraising evidence for nursing practice. Ninth ed. Lippincott Williams \& Wilkins

Pomey, M. P., Ghadiri, D. P., Karazivan, P., Fernandez, N., \& Clavel, N. (2015). Patients as partners: A qualitative study of patients' engagement in their health care. PLoS ONE, 10(4), 1-19. https://doi.org/10.1371/journal.pone.0122499

Rainey, H., Ehrich, K., Mackintosh, N., \& Sandall, J. (2015). The role of patients and their relatives in "speaking up" about their own safety - a qualitative study of acute illness. Health Expectations, 18(3), 392-405. https://doi.org/10.1111/hex.12044

Ringdal, M., Chaboyer, W., Ulin, K., Bucknall, T., \& Oxelmark, L. (2017). Patient preferences for participation in patient care and safety activities in hospitals. BMC Nursing, 16(1), 1-8. https://doi.org/10.1186/s12912-017-0266-7

Schwappach, D. L. B. (2010). Engaging patients as vigilant partners in safety: A systematic review. Medical Care Research and Review, 67(2), 119-148. https://doi.org/10.1177/1077558709342254

Schwappach, D. L. B., Hochreutener, M. A., \& Wernli, M. (2010). Oncology nurses' perceptions about involving patients in the prevention of chemotherapy administration errors. Oncology Nursing Forum, 37(2). https://doi.org/10.1188/10.ONF.E84-E91

Skagerström, J., Ericsson, C., Nilsen, P., Ekstedt, M., \& Schildmeijer, K. (2017). Patient involvement for improved patient safety: A qualitative study of nurses' perceptions and experiences. Nursing Open, 4(4), 230-239. https://doi.org/10.1002/nop2.89

Slawomirski, L., Auraaen, A., \& Klazinga, N. (2017). The economics of patient safetystrengthening a value-based approach to reducing patient harm at national level: Organisation for Economic Cooperation and Development-OECD 
(https://www.oecd.org/els/health-systems/The-economics-ofpatient-safety-March2017 accessed 12 October 2020)

Tappen, R. M. (2016). Advanced nursing research: From theory to practice.Jones \& Bartlett Publishers.

Tobiano, G., Bucknall, T., Marshall, A., Guinane, J., \& Chaboyer, W. (2015). Nurses' views of patient participation in nursing care. Journal of Advanced Nursing, 71(12), 2741-2752. https://doi.org/10.1111/jan.12740

World Health Organization (2019). Patient Safety; Global action on patient safety. (https://www.who.int/news-room/fact-sheets/detail/patient-safety, accessed 12 October 2020)

Wu, T., \& Li, L. (2017). Evolution of Public Health Education in China. American Journal of Public Health, 107(12), 1893-1895. doi:10.2105/ajph.2017.304110 